\title{
Using Debates on Family Issues with Undergraduate Students: The 5 R's Strategy for Promoting Skill Development and Attitude Change*
}

\author{
Patricia Hrusa Williams \\ Towson University
}

\begin{abstract}
*Please address all correspondence to: Dr. Patricia Williams, Department of Family Studies and Community Development, Towson University, 8000 York Road, Towson, MD 21252-0001; Phone: (410) 704-4871; Fax: ; E-mail: pwilliams@towson.edu.
\end{abstract}

\begin{abstract}
This study examines how family issue debates can be used to develop academic, communication, and critical thinking skills among undergraduate students. Students ( $\mathrm{n}=94)$ used the 5 R's Strategy (Reading, Rapping, (w)Riting, Reporting, Repeating) to prepare for the debates, after which they participated in two debates on family issues and observed five. Changes in attitudes and skills were examined with the sample. Over $75 \%$ of students reported that exposure to the debates provided them with new strategies for analyzing complex issues; 31.5 - 39\% reported changes in their attitudes. Students' skills in debating and analyzing issues also increased. Strategies for implementing debates are discussed.
\end{abstract}

Keywords: Attitudes, Communication Skills, Controversy, Critical Thinking, Debates, Family Issues

Debates often are used as a teaching strategy in the fields of family science, psychology, sociology, political science, and social work. As a teaching strategy they hold promise as a tool to assist students in developing critical analysis skills. For example, debates can make students aware of differences in the perspective of family scientists and practioners when considering the same issue, serving to broaden their understanding of complex issues (Steiner, Brzuzy, Gerdes, \& Hurdle, 2003; Omelicheva \& Avdeyeva, 2008). Debates also can create challenges for instructors. Students may hold strong opinions on issues, producing situations where instructors need to manage potentially high levels of conflict and emotion among students (Kennedy, 2007). For students who come to class with established attitudes on issues debates may also merely reinforce 
stereotypical views that they already hold (Budesheim \& Lundequist, 2000) that may not be conducive to working with diverse individuals and families.

The purpose of this article is to review the research on using debates as a teaching strategy. To do so, the 5 R's (Reading, Rapping, (w)Riting, Reporting, and Repeating) Strategy for using debates in a child development course is presented along with data on the effectiveness of this technique in promoting student skill development and broadened attitudes about child, parent, and family issues. While the 5 R's strategy has been used in writing courses (Gutkind, 1996; Williams, 2008), the technique has been adapted here for use in analyzing debates in family science. Finally, strategies for the effective use of debates in a classroom setting with students are outlined.

\section{Why Use Debates?}

The National Council on Family Relations (2009) has identified topics that family life educators need as part of their academic preparation, including a set of practice skills necessary to be effective in the field. They require students receive instruction and tools to analyze how family systems, society, and laws impact the well-being of children, parents, and families. They also require educators to develop students' skills in applying theory and research, evaluating solutions to solve social problems, and broadening their views so they can develop new solutions to the challenges families face. Consistently, many family science disciplines recognize information literacy, communication skills, sociocultural awareness, and the development of critical thinking skills as key undergraduate learning goals (Dunn, McCarthy, Baker, Halonen, \& Gill, 2007; Ganong, Colemen, \& Demo, 1995; Halonen et al., 2002; Steiner et al., 2003). Research on employers' perspectives show they are looking for communication skills, problem-solving abilities, and global knowledge in graduates (Benson et al., 2006; P.D. Hart Research Associates, 2008).

Debates which are used to examine and present opposing arguments and evidence on timely, real-world issues seem an ideal strategy to reach these curricular goals. Debate is a means of examining and discussing differing points of view, with the goal of determining the most plausible and effective solution for an issue (Kennedy, 2007). The debate process allows students to explore family research, tying it to applied issues and topics that bridge disciplines such as psychology, education, law, and medicine. Participating in debates can build students' communication and critical thinking skills. Further, by observing debates they are being exposed to critical issues families experience, which may enhance students' awareness of myriad viewpoints and perspectives (Allen \& Crosbie-Burnett, 1992). As an active learning strategy, it also encourages participation in class.

\section{What Do We Know about Debates as a Teaching Strategy?}

The use of debates as a teaching strategy is associated with a variety of positive outcomes for students. For example, studies have found that debate exercises increase student interest, engagement, and participation (Elliot, 1993; 
Lewin \& Wakefield, 1983). Research also finds that students' exposed to debate exercises feel the experience benefits their critical thinking skills (Steiner et al., 2003), helps them retain factual information (Koklanaris, MacKenzie, Fino, Arslan, \& Seubert, 2008), and increases awareness of important issues in the field (Omelicheva \& Avdeyeva, 2008). Studies comparing debates versus lectures as teaching strategies find that students exposed to debates perform better on assessments examining comprehension of concepts (Omelicheva \& Avdeyeva, 2008).

Despite these strengths, Kennedy's (2007) review of the literature suggests challenges in using debates. They include that debates often include the examination of two versus multiple sides of an issue, contribute to an adversarial feel in the classroom, and limit the potential for learning to those actively involved in the in-class debate. Most troubling is the assertion that debates may only be used by students to reinforce their existing attitudes on an issue rather than to broaden or enhance their knowledge of alternate perspectives. Empirical research has found that students have implicit theories about human nature and personality that are resistant to change during the course of a semester (Wang, 2000). Studies examining debates finds that the majority of undergraduate students maintain their position on the issues debated (Landrum, 1991; Moeller, 1985; Steiner et al., 2003). While not always problematic, it is important to consider whether these pre-existing attitudes are grounded in strong, reliable data, that they match the code of ethics, beliefs, and standards ascribed to for their future profession, and are conducive to working with diverse individuals and families.

Situational factors also are associated with attitude change in college students. Greater attitude change has been found when exploring topics using a debate rather than a lecture format (Omelicheva \& Avdeyeva, 2008). However, attitude change is dependent on two factors noted by Budesheim and Lundquist (2000). They found that students were more likely to change their attitudes when they represented a position in a debate which was not consistent with their original attitude. Students also were less likely to change their attitude on topics with which they had more personal experience, such as issues related to families and culture. It is also important to consider when and how attitude change is assessed in understanding when and how it occurs. In fact, some studies have not examined student attitude change directly pre- and post participating or observing the debate. For example, Steiner and associates (2003) only examined attitudes and their change through an end of semester assessment. The rigor and depth of the analysis of multiple sides of the issue required as part of the assignment also may be crucial in promoting changes in views.

Since debates can be more of a hindrance than a help if they only serve to confirm students' stereotypes and preconceptions about an issue (Budesheim \& Lundequist, 2000) without expanding their ideas in some way, it is important to construct debate exercises so their purpose is "not to resolve the debate... (but to) analyze arguments logically and critically" (Peet, 2005, p. 13). Meizrow (1996; 1997) suggests that true learning is transformative in that it changes our way of 
looking at issues and experiences. Learning in his framework occurs when we critically reflect on the assumptions upon which viewpoints are rooted (Meizrow, 1997). As such, attitude change and perhaps a movement toward indecision on issues for which you were previously confident can be considered a positive learning outcome. Being able to see multiple considerations or factors that need to be taken into account may create dissonance or disequilibrium, which is a necessary step in the process of cognitive development (Piaget, 1926; 1928). This in turn may allow students to see the issue from a multidimensional, rather than binary, perspective. For example, they may come to understand under what circumstances a solution, policy, or perspective on an issue may be more or less beneficial to children, parents, and families.

To truly understand family issues, students need to be able to analyze arguments, recognize bias, be open to new ideas, and develop sound arguments based on reasoning and defensible evidence (Wade, 2000). High quality debates are ones where the debaters are knowledgeable and well-researched about both sides of the issue, present and defend their points empirically, and are perceptive and prepared to address the weaknesses in their position and that of the opposing side (Berg, 1979; Morahan-Martin, 1986; Smith, 1990). For this reason preparatory guidance provided prior to students engaging in a debate is needed. Strategies suggested include the use of out of class conversations, outside readings, and a structured writing assignment to encourage students to explore both sides of the issue (Landrum, 1991; Moeller, 1985; Peet, 2005). These strategies are important to produce high-quality debates that engage students, given some research suggests that the majority of students prefer participating to observing debates (Elliot, 1993).

\section{A Model for Using Debates in the Classroom}

A model called the 5 R's Strategy was developed as a means to prepare students to produce high quality debates, promote growth in students' debate skills, and produce broadened views on family issues. The strategy includes the following components:

1. Reading: All students in the course were required to read two research articles representing different views on each issue. Articles were taken from the book Taking Sides: Childhood and Society, edited by DelCampo and DelCampo (2004).

2. Rapping: Students participating in the debate meet with the instructor as a group before the debate to discuss the readings, ask questions, and brainstorm ways to approach the debate.

3. (W)Riting: Students participating in the debate complete an individual written assignment that incorporates objectives suggested by Wade (2000). Students are required to define the problem or controversy, find core disagreements across the two opposing arguments, recognize bias and persuasive strategies, evaluate the empirical merit of data, and find and evaluate an outside primary source to further explore the issue or controversy. 
4. Reporting: Students lead and participate in a 40-minute debate during a class period. The debate is introduced and moderated by the instructor.

5. Repeating: Students participate in one debate during the first half of the semester and one during the second half of the semester so they have an opportunity to develop and strengthen their skills by repeating the 5 R's Strategy when examining a new controversial issue in family science.

This strategy is reflective of Meizrow's (1996) conception of adult literacy as "rationale discourse" (p. 6). The process enables students to learn both instrumentally and communicatively, using a combination of independent reading, listening to different points of view, active learning in a small and large group context, and reflection which occurs repeatedly during the semester, with the instructor acting as a facilitator to guide the learner (Meizrow, 1997). The 5 R's Strategy suggested here is similar to other 5 R's frameworks suggested by both Gutkind (1996) and Williams (2008). However, both of these models view argument analysis from the perspective of English composition and as a selffocused, writing-oriented process involving reading, research, writing, rhetorical and real-world analysis, and revision. The perspective suggested here has adapted their models, making it broader and requiring students to learn how to analyze debates using multiple strategies including individual reading and writing, small group discussion, and oral presentation of the issue to a larger group. This larger exchange of ideas within the context of the classroom environment and use of group processes are keys to educational growth in Meizrow's (1997) model.

The 5 R's Strategy suggested here also requires more of students participating in debates than has been reported in other empirical studies of debates. Although both Moeller (1985) and Landrum (1991) used written assignments, they were only required of non-debaters as a means to keep them engaged in the debate. None of the research on debates has examined the role of requiring students to prepare for and participate in more than one debate to examine if students' actual ability to analyze and debate issues changes over the course of a semester. The goal of the present study is to explore this question. The study also examines if the 5 R's Strategy contributes to improved debate quality and attitude change in both participants and observers of debates assessed directly prior to and after exposure to the debate. A move toward a more multidimensional or undecided attitude on issues can be viewed as a positive cognitive change. It suggests that students no longer view issues as simplistically as they did prior to the debate, perhaps acknowledging that there are a variety of factors to take into account when deciding whether a practice or policy is beneficial or not to children and families.

\section{Participants}

\section{Method}

Students in four different sections of the same upper-level child development course $(\mathrm{N}=94)$ participated in two debates and observed five debates on family issues. Debate topics examined research on (1) whether the welfare of children in society is improving, (2) if maternal employment is harmful 
to young children's development, (3) if institutional child care is the best setting to intervene in the lives of young children, (4) the benefits of bilingual education, (5) the effects of transracial adoption, (6) whether family preservation should be used with abusive families, and (7) whether viewing television violence has longterm negative effects on children. The majority of the students in the course were third $(47.9 \%)$ and second year $(26.6 \%)$ college students, with fewer first and fourth year students enrolled (10.6\% and $14.9 \%$, respectively).

\section{Procedure}

There were seven debates during the semester. Students participated in two debates and observed five. The debates and the requirements for the assignment were introduced during a class period at the start of the semester. Students were then allowed to sign-up for debates that best accommodated their interests and schedule. Up to eight students could participate in a debate, with four students representing each side of the issue. Students could choose the debate and side they represented, if space was available. Additionally, students were required to participate in one debate during the first half of the semester and one in the second half. This would allow students the opportunity to use the feedback they received from the first debate assignment and apply what they learned to analyze and debate a different issue later in the semester.

In preparation for the debate students were required to utilize the $5 \mathrm{Rs}$ Strategy (Reading, Rapping, (w)Riting, Reporting, Repeating). They read two conflicting articles on the controversial issue being debated from the book Taking Sides. After reading the articles, the debate groups were required to schedule a meeting to talk or rap with the instructor regarding the issue. The purpose of the half-hour meeting was to answer any questions students had about the debate readings, writing assignment, or the actual debate. The instructor strategized with groups regarding how they could approach the debate and shared with each group empirical studies and resources which they could use in their preparation.

Students also were required to write an individual paper on the debate issue. Students were required to analyze the issue being debated, examining both sides of the issue objectively. Students' papers were to be 4-5 pages in length. Students needed to state the issue and the viewpoints of each side in their own words. They needed to look across the articles to identify two main areas of disagreement, biases in the presentation of the information, and the empirical merits of each side. Students also needed to find an outside primary source article which they summarized and tied to the debate. Only in the last section of the paper were students allowed to give their opinion on the issue, after analyzing both sides. The student writing assignment was due in class prior to the actual debate. It was graded using a rubric developed by the instructor who did not know the students' identity when grading the paper.

Finally, students reported their information to the larger class in the context of an in-class debate. Debate teams presented information in the context of a 40 minute debate moderated by the instructor. The debate was divided into three phases. During the first phase, which lasted approximately 15 minutes, 
student groups presented their team's position and a summary of the evidence supporting it. During the second phase, which was also approximately 15 minutes in length, members of each side were free to question the other team regarding points they had made or data they had presented. During the final ten minutes, the debate was opened up to the audience who were free to ask questions of each side. Student debate teams could obtain a maximum score of 10 points depending on the quality of their debate performance. Five points were awarded by their classmates and 5 awarded by the instructor. A description of how debate quality was assessed follows.

\section{Measurement}

Debate quality. Debate groups representing each side of an issue were evaluated both by fellow students and the instructor. Instructor and student evaluation forms included five questions used by Berg (1979), Morahan-Martin (1986), and Smith (1990) to measure debate performance. Questions evaluated how prepared, organized, empirical, perceptive of weaknesses in arguments, and effective each team was when completing the in-class oral debate. Each of the five questions was rated on a 5-point scale, with lower scores indicating poorer debate performance and quality. Student debate scores were averaged across the 5 questions to obtain a score of overall debate quality for each debate.

End of semester assessment of the assignment. Students also completed an overall evaluation of the debate assignment at the end of the course. They rated the degree to which they believed the writing assignment helped them think more critically about the issues, the support provided by the instructor in preparing for the debate, and their attitude about the general value of the assignment using a 5point scale with lower scores indicating poorer ratings or more negative perceptions. In addition to this quantitative data, qualitative data also was collected. Students responded to open-ended questions regarding what they believed they learned from the debate series and the strengths/weaknesses of the assignment and series.

Student attitudes on family issues. Each student who observed and participated in the debate was required to provide information pertaining to their attitude on the issue during the same class period, pre- and post-observing the debate. At both time points students noted whether they supported the pro side, the con side, a combination of the pro and con side, or neither side of the issue being debated. They also were asked to report whether exposure to the debate changed their attitude on the issue, using the options 'changed', 'unchanged', or 'undecided'.

Students' analytic skills. Students were asked directly after the debate if the debate provided them with more strategies to analyze and consider complex issues, such as those presented in the debate, using the options 'yes', 'no' or 'undecided'. 
Students' debate skills. The average 5-point score awarded by both fellow students and the instructor for debate performance were added together with the students' score on the 30-point written assignment to obtain a score out of a possible 40 points for the debate assignment. A similar score was calculated after the second debate.

\section{Results \\ Quality of Student Debates and Assignment}

As indicated in Table 1, students' perceptions of the quality of the debates were high, averaging 4.68 out of 5 points. Students' perceptions of the quality of the debate series and supports provided to students were somewhat lower and more variable, averaging 3.78; student were most satisfied with the quality of the writing assignment $(M=3.95)$ and least satisfied with the quality of the readings used as the stimulus for the debate $(M=3.51$ out of 5$)$.

\section{Stability and Change in Students' Attitudes on Debate Issues}

Table 2 contains data examining changes in students' attitudes before and after each debate. On average more than one third of students experienced a change in attitude, with almost one-quarter moving to more-multidimensional or undecided positions on issues. More students changed their attitude on the effects of maternal employment (39\%) than changed their view on family preservation efforts as a means to address child maltreatment (31.5\%). For 6 of the 7 debates there were no difference in attitude change between those who participated or observed a debate, $\chi^{2}(2, \mathrm{~N}=78-86)=.847-4.138, p>.10$. For the debate on family preservation, observers were more likely to change their opinion or be undecided on the issue than debate participants $(73.1 \%$ vs. $26.9 \%$ and $90.5 \%$ vs. $9.5 \%$ respectively, $\chi^{2}(2, \mathrm{~N}=83)=10.44, p=.005$. Table 3 contains data examining changes in students' ideas and perceived analytic skills. On average $36.7 \%$ reported their ideas on the issue changed; slightly more than the number who had reported that a change in attitudes about the issue. Further, 79.4\% reported that exposure to the debate had provided them with more strategies to analyze and consider complex issues.

\section{Debate Quality and Attitude Change}

In the first three debates, those who remained undecided regarding debate topics rated debates as being of a lower overall quality compared to those who made a decision (either their views changed or remained unchanged). The average score for debate quality given by those who reported they were undecided after each of the first three debates was 4.33 while those who made a decision regarding their attitude on the issue rated the quality of the debate as $4.67, t(75)=$ 2.786, $p=.012$. After the first three debates, debate quality was not related to attitude change, $t(81)=1.008, p=.352$. 


\section{Changes in Students' Analytic and Debate Skills}

Analyses using a paired t-test found a statistically significant change in students' analytic and debate skills from the first debate assignment to the second, controlling for students' year in college. Students combined scores on the written assignment and in-class debate, worth a total of 40 points, increased across the two debate assignments from 34.07 to $36.38, t(93)=-8.94, p=.0001$.

\section{Overall Views on Debates as a Teaching Strategy}

The majority of students in the course stated the debates provided them with skills and strategies to analyze and consider complex issues that could be applied to other problems. When asked specifically "What is the most important thing you learned as a result of the debate series?" most reported that the series had broadened their views on issues and developed their critical thinking skills (see Table 4). Their comments suggest that the debate helped them not only see two sides, but multiple sides of an issue. Table 5 contains information regarding students' comments about how to improve the assignment and series. Students identified two major weaknesses of the assignment. One weakness is that $40.5 \%$ reported wanting stronger, richer articles that could serve as the stimulus for the debate. Another weakness focused on the debate performance of the teams. Since debaters were forced with the 5 R's strategy to prepare in advance for the debate, it sometimes seemed that the debates were more formal presentations than active and evolving conversations about the topic between the teams. As a result, some students thought the debates could be sometimes boring to watch.

\section{Discussion}

This study suggests that use of the 5 R's Strategy for implementing debates holds promise as a tool for mentoring future generations of students in family life education and family science. Prior research on debates suggests immersion in a critical thinking environment (Gray, 2000) by observing and participating in debates positively influences the development of students' communication and critical thinking skills. However, others have highlighted the need for explicit instruction (Wade, 2000; Williams, Oliver, Allin, Winn, \& Booher, 2003) in order to truly develop students' ability to analyze issues. This study incorporated both strategies by using a debate series in combination with explicit instruction provided through student-instructor meetings and a writing assignment that required students to analyze opposing positions in writing. Since the writing assignment was repeated during the semester, it enabled students to obtain feedback on their analysis of the first debate issue that could be incorporated into the second assignment. It appears this strategy produced growth in students' debate skills during the course of the semester.

Though a labor intensive approach which combined reading, writing, observing and participating in a series of debates, this technique helped the majority of students (over 75\%) see new strategies to analyze complex issues. Further, students rated the writing assignment and instructor meetings as valuable. They used instructor assistance to answer questions, find additional sources, 
obtain ideas about how to structure debates, and respond to challenges by the other debate team. Small class sizes ( 25 students each) helped facilitate use of his strategy. Additionally, informal data gained by talking to students suggests some indirect benefits of using the 5 R's Strategy. Students often cited more class cohesion, more comfort in participating, and more dialogue between students and the instructor as benefits.

In-class debates helped one-third of students to revise their attitude on issues, regardless if they were directly involved in the debate or not. This is a greater percentage than has been found in other studies of debates, where rates of attitude change hover between 11.8 - 28.6\% (Landrum, 1991; Steiner et al., 2003). The pre- and post-assessment of attitudes directly prior to and following the actual debate may have served as a more reliable and valid measure of attitude change than looking at changes in attitudes from the beginning of the semester and then after the debate (Budesheim \& Lundequist, 1999) or assessing pre- and postdebate attitudes in an end of semester assignment only (Steiner et al., 2003). However, it is also important to keep in mind that debate quality and the type of family issue being discussed were important to attitude change. This study found that quality counts, especially in the early stages of a debate series. Lower quality debates may reinforce students' stereotypes or not provide enough breadth for students who are undecided to clarify their views. The majority of students were quite generous in the scores they assigned to their fellow debaters, believing their peers took the assignment seriously. While the amount of preparation required of debaters produced debates of reasonably high quality, it did not guarantee that students always believed the debates were interesting to watch, as Elliot (1993) observed.

Debates sometimes seemed more like presentations, with limited amounts of questioning and dialogue between the two sides. Strategies that may be employed to improve the implementation of debates include getting help from a professional, such as a high school or college debate coach, (see Elliot, 1993) and observing a televised debate to consider tactics and strategies that can be used (see Shapiro, 2000). One strategy I currently incorporate is a website and message board that is associated with each debate, requiring non-debaters to provide questions and feedback prior to class. The submission of questions aids teams in preparing for debates and may serve to draw other students into the discussion.

The topic being discussed also is key to understanding attitude change when using debates. While Budesheim and Lundquist (2000) found that students were less likely to change their attitude on topics with which they had more personal experience, this study found the opposite. Students in a child development course were more likely to change their attitude on the effects of maternal employment, a phenomenon that many of them have experienced. They were less likely to change their attitude about family preservation efforts, a topic which they knew less about from personal experience or the textbook used in the course. Since most child development texts, including the one used in this course, focus more on the negative effects of child maltreatment it may have been challenging for students to warm-up to the idea that there can be benefits to 
reuniting these types of families. This finding highlights the need for instructors to incorporate strength-based and empowerment models of family development into their courses to counter the trend found in many traditional textbooks in psychology.

All critical thinking exercises are not created equal. Care needs to be taken in selecting stimulus readings to explore debate issues. While there are several commercially available series which contain articles to use as part of a debate assignment, many are shortened versions of scholarly published sources. They may not contain all of the data on the research methods and results of a study that a debater may need to be able to develop their arguments. Providing a variety of rubrics or frameworks for examining the assumptions of a theory or argument also is needed so students understand the many sides to one issue (Yanchar \& Slife, 2004). In my course I post additional resources for analyzing arguments and positions, such as those offered as part of the Taking Sides curriculum. The more materials, sources, and ideas the debaters are forced to confront before they enter the oral, in-class debate, the better they can anticipate and respond to questions in class. Similarly, limiting choice within the assignment is vital. Allowing students to choose the issue they debate, but not necessarily the side they represent, enables forced examination of the alternatives (see Bundesheim and Lundquist, 2000). In subsequent semesters I have randomly assigned students to their sides during the class prior to the debate.

There is still much to be learned about how best to develop critical thinking skills in the context of the classroom and the curriculum. This study demonstrates that combining immersion in a critical thinking environment through a debate series with explicit instruction in how to approach the debate issue is an effective approach to help nurture the next generation of family life educators and family scientists. As instructors, we also need to consider the habits of mind we encourage in our students. Content knowledge in the field of family science is important. However, it is crucial that we further develop techniques like the 5 R's Strategy in order to produce students with information literacy, communication skills, sociocultural awareness, and the ability to consider the new perspectives and solutions to the evolving challenges families in society face.

\section{References}

Allen, K.R., \& Crosbie-Burnett, M. (1992). Innovative ways and controversial issues in teaching about families: A special collection on family pedagogy. Family Relations, 41, 9-11.

Benson, J.M., Allen, R.K., Few, L.A., Roberto, A.K., Blieszner, R., Mezaros, S.P., et al. (2006). Transforming the master's degree in Human Development and Family Science. Family Relations, 55, 44-55.

Berg, B. (1979). Panel discussions in the classroom. Teaching of Psychology, 6, 242-243. 
Budesheim, T. L. \& Lundquist, A. R. (2000). Consider the opposite: Opening minds through in-class debates on course-related controversies. In M. R. Hebl, Brewer, \& L. T. Benjamin (Eds.) Handbook of demonstrations and activities in the teaching of psychology $\left(2^{\text {nd }}\right.$ ed.): Volume 2. New Jersey: Erlbaum.

DelCampo, D. S. \& DelCampo, R. L. (Eds.) (2004). Taking Sides: Clashing Views on Controversial Issues in Childhood and Society (Fifth Edition). McGraw-Hill/Dushkin: Guilford, CT.

Dunn, D. S., McCarthy, M.A., Baker, S., Halonen, J. S., \& Hill, G. W. (2007). Quality benchmarks in undergraduate psychology programs. American Psychologist, 62(7), 650-670.

Elliot, L. B. (1993). Using debates to teach the Psychology of Women. Teaching of Psychology, 20(1), 35-38.

Ganong, L.H., Coleman, M., \& Demo, D.H. (1995). Issues in training family scientists. Family Relations, 44, 501-507.

Gray, P. (2000). Engaging students' intellects: The immersion approach to critical thinking in psychology instruction. In M.R. Hebl, C. L. Brewer, \& L. T. Benjamin (Eds.), Handbook of demonstrations and activities in the teaching of psychology: Volume 2. New Jersey: Erlbaum.

Gutkind, L. (1996). The 5 Rs of creative nonfiction. Creative Nonfiction, 6, 1-14.

Halonen, J.S., Appleby, D.C., Brewer, C. L., Buskist, W., Gillem, A.R., Halpern, D.F. et al. (APA Task Force on Undergraduate Major Competencies). (2002). Undergraduate psychology major learning goals and outcomes: A report. Washington, DC: American Psychological Association.

Kennedy, R. (2007). In-class debates: Fertile ground for active learning and the cultivation of critical thinking and oral communication skills. International Journal of Teaching and Learning in Higher Education, 19(2), 183-190.

Koklanaris, N. MacKenzie, A.P, Fino, M.E., Arslan, A.A. \& Seubert, D.E. (2008). Debate preparation/participation: An active, effective learning tool. Teaching and Learning in Medicine, 20(3), 235-238.

Landrum, R.E. (1991). Student evaluation of classroom debates. College Student Journal, 25, 163-165. 
Lewin, L. M., \& Wakefield, J. A. (1983). Teaching psychology through an instructor-debate format. Teaching of Psychology, 10(2), 115-116.

Meizrow, J. (1996). Toward a theory of adult literacy. Adult Basic Education, $6(3), 115-126$.

Meizrow, J. (1997). Transformative learning: Theory to practice. New Directions for Adult and Continuing Education, 74, 5-12.

Moeller, T. G. (1985). Using debates in teaching developmental psychology. Teaching of Psychology, 12(4), 207-209.

Morahan-Martin, J. (1986, August). The great debate: Using a debate format in introduction to psychology. Paper presented at the annual meeting of the American Psychological Association, Washington, DC.

National Council on Family Relations (NCFR) (2009). Family life education content areas: Content and practice guidelines. Minneapolis, $\mathrm{MN}$ : Author.

Omelicheva, M.Y., \& Avdeyeva, O. (2008). Teaching with lecture or debate? Testing the effectiveness of traditional versus active learning methods of instruction. PS: Political Science and Politics, 41, 603-607.

P.D. Hart Associates (2008). How should colleges assess and improve student learning? Employers' views on the accountability challenge. Washington, D.C.: Author.

Peet, S.H. (2005). Controversy and critical thinking involving African-American families. Inquiry, 24(1-2), 13-19.

Piaget, J. (1926). The language and thought of the child. New York: Harcourt, Brace \& World.

Piaget, J. (1928). Judgment and reasoning in the child. New York: Harcourt, Brace, \& World.

Shapiro, J. K. (2000). Dr. Kohlberg goes to Washington: Using congressional debates to teach moral development. In M. R. Hebl, C. L. Brewer, \& L. T. Benjamin (Eds.), Handbook of demonstrations and activities in the teaching of psychology: Volume 2. New Jersey: Erlbaum.

Smith, R. A. (1990). Are peer ratings of student debates valid? Teaching of Psychology, 17(3), 188-189. 
Steiner, S., Brzuzy, S., Gerdes, K. \& Hurdle, D. (2003). Using structured controversy to teach diversity content and cultural competence. Journal of Teaching in Social Work, 23(1/2), 55-71.

Wade, C. (2000). Using writing to develop and assess critical thinking. In M. R. Hebl, C. L. Brewer, \& L. T. Benjamin (Eds.), Handbook of demonstrations and activities in the teaching of psychology: Volume 2. New Jersey: Erlbaum.

Wang, A. Y. (2000). Making implicit personality theories explicit: A classroom demonstration. In M. E. Ware \& D. E. Johnson (Eds.), Handbook of demonstrations and activities in the teaching of psychology $\left(2^{\text {nd }}\right.$ ed.): Volume 3. New Jersey: Erlbaum.

Williams, M. (2008). Teaching composition as fun with real audio [Web log post]. Retrieved from http://blog.lib.umn.edu/will1923/matthew/2008/05/teaching_composition as_fun_wi_1.html.

Williams, R. L., Oliver, R., Allin, J. L., Winn, B., \& Booher, C. S. (2003). Psychological critical thinking as a course predictor and outcome variable. Teaching of Psychology, 30(3), 220-223.

Yanchar, S. C. \& Slife, B. D. (2004). Teaching critical thinking by examining assumptions. Teaching of Psychology, 31(2), 85-90.

\section{Author Note}

I wish to thank the students at Providence College who participated in this study. In addition I wish to thank Bradley van Eeden-Moorefield and anonymous reviewers at the Michigan Family Review for their helpful comments. 
Table 1. Descriptive Statistics for Debate and Assignment Quality Variables.

\begin{tabular}{llll}
\hline Variables & $M$ & $S D$ & Range \\
\hline Overall student-rated quality of each debate $(N=76-$ & & & \\
85) & & & \\
Debate 1: Welfare of disadvantaged children & 4.65 & .39 & $3.5-5$ \\
Debate 2: Maternal employment & 4.65 & .30 & $3.5-5$ \\
Debate 3: Institutional child care & 4.48 & .47 & $3.1-5$ \\
Debate 4: Bilingual education & 4.65 & .34 & $3.80-5$ \\
Debate 5: Transracial adoption & 4.74 & .34 & $3.4-5$ \\
Debate 6: Family preservation & 4.70 & .34 & $3.6-5$ \\
Debate 7: TV violence & 4.71 & .39 & $3.6-5$ \\
Overall average student-rated quality of the debates & 4.68 & .27 & $3.93-5$ \\
Overall student-rated quality of the debate series and & & & \\
supports provided students $(N=82)$ & & & \\
Readings & 3.51 & .80 & $1-5$ \\
Writing assignment & 3.95 & .80 & $2-5$ \\
Meetings to set-up and discuss debate & 3.74 & .97 & $1-5$ \\
Overall assignment & 3.78 & .86 & $1-5$ \\
\hline & & & \\
\hline
\end{tabular}


Table 2. Stability and Change in Students' Attitudes on Debate Issues.

\begin{tabular}{|c|c|c|c|c|c|}
\hline \multirow[t]{2}{*}{ Debate } & \multicolumn{3}{|c|}{$\begin{array}{c}\text { Change in position after } \\
\text { debate }\end{array}$} & \multicolumn{2}{|c|}{$\begin{array}{l}\text { Type of change in } \\
\text { position }\end{array}$} \\
\hline & $\begin{array}{l}\text { No } \\
\text { change } \\
(\%)\end{array}$ & $\begin{array}{l}\text { Change } \\
(\%)\end{array}$ & $\begin{array}{l}\text { Total } \\
(\%)\end{array}$ & $\begin{array}{l}\text { Change: } \\
\text { Singular } \\
\text { position } \\
(\%)\end{array}$ & $\begin{array}{l}\text { Change: } \\
\text { Combined or } \\
\text { undecided } \\
\text { position }(\%)\end{array}$ \\
\hline $\begin{array}{l}\text { Debate } \# 1: \text { Welfare of } \\
\text { disadvantaged children }(n=81)\end{array}$ & 58.0 & 42.0 & 100 & 16.0 & 26.0 \\
\hline $\begin{array}{l}\text { Debate \#2: Maternal employment } \\
(n=86)\end{array}$ & 61.0 & 39.0 & 100 & 18.0 & 21.0 \\
\hline $\begin{array}{l}\text { Debate \#3: Institutional child care } \\
(n=78)\end{array}$ & 68.0 & 32.0 & 100 & 8.0 & 24.0 \\
\hline $\begin{array}{l}\text { Debate \#4: Bilingual education }(n= \\
85)\end{array}$ & 62.0 & 37.0 & 100 & 18.5 & 18.5 \\
\hline $\begin{array}{l}\text { Debate \#5: Transracial adoption ( } n \\
=87 \text { ) }\end{array}$ & 64.0 & 36.0 & 100 & 7.0 & 29.0 \\
\hline $\begin{array}{l}\text { Debate \#6: Family preservation ( } n \\
=83 \text { ) }\end{array}$ & 67.5 & 31.5 & 100 & 6.0 & 26.5 \\
\hline Debate \#7: TV violence $(n=85)$ & 67.0 & 33.0 & 100 & 4.0 & 29.0 \\
\hline Average across debates & 64.0 & 34.4 & & 13.0 & 24.8 \\
\hline
\end{tabular}


Table 3. Change in Students' Ideas and Self-Reported Analytic Strategies.

\begin{tabular}{lll}
\hline Variables & $\begin{array}{l}\text { \% Reporting } \\
\text { a change in } \\
\text { ideas }\end{array}$ & $\begin{array}{l}\text { \%eporting } \\
\text { more strategies } \\
\text { to analyze } \\
\text { complex issues }\end{array}$ \\
\hline $\begin{array}{l}\text { Debate 1: Welfare of disadvantaged children }(\mathrm{n} \\
=79)\end{array}$ & 46.8 & 77.2 \\
Debate 2: Maternal employment $(\mathrm{n}=84)$ & 39.8 & 84.5 \\
Debate 3: Institutional child care $(\mathrm{n}=77)$ & 32.5 & 76.3 \\
Debate 4: Bilingual education $(\mathrm{n}=83)$ & 42.2 & 80.7 \\
Debate 5: Transracial adoption $(\mathrm{n}=86)$ & 34.9 & 81.2 \\
Debate 6: Family preservation $(\mathrm{n}=83)$ & 31.3 & 79.3 \\
Debate 7: TV violence $(\mathrm{n}=86)$ & 29.1 & 76.7 \\
Average across debates & 36.7 & 79.4 \\
\hline
\end{tabular}


Table 4. What Students Learned from the Debate Series $(n=80)$.

\begin{tabular}{|c|c|c|}
\hline Skill area & $\begin{array}{l}\% \text { of } \\
\text { responses }\end{array}$ & Representative student quotes \\
\hline $\begin{array}{l}\text { Broadened } \\
\text { views on issues }\end{array}$ & $41.25 \%$ & $\begin{array}{l}\text { "...that there are many different sides to issues } \\
\text { that I have only seen one side of." } \\
\text { "...that I had pretty narrow views on a lot of } \\
\text { issues and had not realized other outside } \\
\text { factors in a lot of cases." } \\
\text { "...the broader extent of these various topics } \\
\text { as well as the complexities within these } \\
\text { issues." }\end{array}$ \\
\hline $\begin{array}{l}\text { Critical } \\
\text { thinking skills }\end{array}$ & $36.25 \%$ & $\begin{array}{l}\text { "How to look at both sides of an argument and } \\
\text { think critically." } \\
\text { "How to look at both perspectives and gather } \\
\text { resources to come to a better understanding of } \\
\text { the topic." } \\
\text { "How to read an article to set-up an argument; } \\
\text { how to find evidence in an article that makes } \\
\text { the argument..." } \\
\text { "The many unique ways to look at opposing } \\
\text { issues." }\end{array}$ \\
\hline $\begin{array}{l}\text { Communication } \\
\text { skills }\end{array}$ & $10.0 \%$ & $\begin{array}{l}\text { "How to write a detailed paper on a } \\
\text { controversial topic..." } \\
\text { "I'm a lot more comfortable speaking in front } \\
\text { of class and at actually debating..." }\end{array}$ \\
\hline $\begin{array}{l}\text { Knowledge } \\
\text { about } \\
\text { important, real } \\
\text { world topics } \\
\text { Total }\end{array}$ & $12.5 \%$ & $\begin{array}{l}\text { "Good way to apply textbook topics to real } \\
\text { world experiences." } \\
\text { "I learned a lot about the organizations that } \\
\text { aim to help child development." }\end{array}$ \\
\hline
\end{tabular}


Table 5. What Students Perceived as Weaknesses of the Assignment and Debate Series $(n=79)$.

\begin{tabular}{|c|c|c|}
\hline Weakness & $\%$ of responses & Representative student quotes \\
\hline $\begin{array}{l}\text { Debate } \\
\text { readings }\end{array}$ & $40.5 \%$ & $\begin{array}{l}\text { "Some of the articles debated were not written in a way that } \\
\text { was very informative or convincing." }\end{array}$ \\
\hline $\begin{array}{l}\text { Student } \\
\text { debate skills }\end{array}$ & $30.4 \%$ & $\begin{array}{l}\text { "...sometimes debates turned into just presentations instead of } \\
\text { seeking out the other team's weak points." } \\
\text { "Groups were too focused on giving every detail of the articles } \\
\text { rather than truly having an open debate." } \\
\text { "People don't know how to break down the other group's } \\
\text { argument in order to have a true debate." }\end{array}$ \\
\hline $\begin{array}{l}\text { Rigor of the } \\
\text { assignment }\end{array}$ & $10.1 \%$ & $\begin{array}{l}\text { "I feel it is good to write papers but I feel there were too many } \\
\text { criteria and there was often not enough time to have a good } \\
\text { debate..." }\end{array}$ \\
\hline $\begin{array}{l}\text { Finding } \\
\text { resources }\end{array}$ & $7.6 \%$ & $\begin{array}{l}\text { "Finding a good empirical article proved to be a bit of a } \\
\text { challenge yet it is important to be able to do the research." }\end{array}$ \\
\hline Group work & $3.8 \%$ & $\begin{array}{l}\text { "Since we didn't really know our debate members it was really } \\
\text { hard to collaborate with them..." }\end{array}$ \\
\hline $\begin{array}{l}\text { Too many } \\
\text { debates }\end{array}$ & $3.8 \%$ & $\begin{array}{l}\text { "It took away from class time. I would have liked to talk more } \\
\text { in-depth about some of the materials in the text." }\end{array}$ \\
\hline $\begin{array}{l}\text { No } \\
\text { weaknesses }\end{array}$ & $3.8 \%$ & "No weakness. The debates were a good part of the class." \\
\hline Total & $100 \%$ & \\
\hline
\end{tabular}

